Received 26.07.2017

Reviewed $\quad 02.02 .2018$

Accepted 13.02 .2018

A - study design

B - data collection

C - statistical analysis

D - data interpretation

$\mathbf{E}$ - manuscript preparation

F - literature search

\section{Optimization of irrigation cropping pattern by using linear programming: Case study on irrigation area of Parsanga, Madura Island, Indonesia}

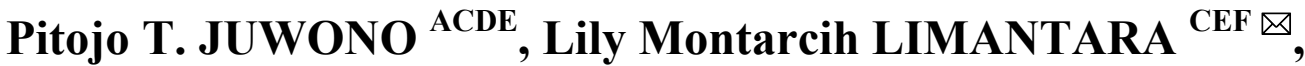 \\ Fathor ROSIADI ${ }^{\text {BD }}$
}

University of Brawijaya, Faculty of Engineering, Department of Water Resources, Jl. Mt Haryono No 167, 65141 Malang, East Java Province, Indonesia; e-mail: pitojo_tj@ub.ac.id; lilymont2001@gmail.com

For citation: Juwono P.T., Limantara L.M., Rosiadi F. 2018. Optimization of irrigation cropping pattern by using linear programming: Case study on irrigation area of Parsanga, Madura Island, Indonesia. Journal of Water and Land Development. No. 39 p. 51-60. DOI: 10.2478/jwld-2018-0058.

\begin{abstract}
The irrigation area of Parsanga is located in Sumenep Regency, Madura Island of Indonesia. This irrigation area is 500 ha and the existing cropping pattern is paddy-paddy-second crop. There is water discharge deficiency due to the existing cropping pattern mainly in the dry season. Thus, this study intends to optimize the cropping pattern for 3 condition so that it can produce the maximum benefit of agricultural product. The first cropping pattern is paddy/second crop-second crop-paddy/second crop; the second proposition is paddy/second crop -paddy/second crop-second crop; and the third proposition is paddy-second crop-paddy/second crop. The optimization analysis is carried out by using the linear programming. The suggested three cropping patterns are not only able to solve the water deficiency; they can also present the more production benefit than the existing condition.
\end{abstract}

Key words: cropping pattern, irrigation, linear programming, optimization, Parsanga

\section{INTRODUCTION}

Management of water resources is not an easy job mainly when the problem is as the national wide. It becomes harder if an area is considered unstable or when the events and climate are unpredictably [INWRDAM 2001]. The regional decision making is considered to a variety of the technical aspects that need to have to be decided. It is an interplayed of the factual base of information about the system, the methods to process this information and the interpretation of the results [GUPTA, ZAAG 2007; PAVONI et al. 2001]. The main objective of water resources management is to solve the formula of demand and supply of water resource for a specific area taking into account various dimensions like space, time, econo- my, politics, environment, and other aspects. Also, water management means the reconciliation of all users, preservation of water and related land resources, and previous of enough water for constantly expanding needs [GUPTA et al. 2010; LIMANTARA 2010a].

Some rivers in Indonesia were progressive developed latterly. The restriction of surface water resources, mainly in the dry season intensify the need for an optimum capacity and operation for the multi purposes reservoir systems [GAKPO et al. 2006; SATTARI et al. 2006]. Furthermore, the monitoring of surface water resources in the terms of quantity is necessary to determine the availability of water, to verify the norms of consumption (e.g. for irrigation) and to calculate the load of substances leaving the catchment 
[MiATKOWSKI, SMARZYŃSKA 2017]. Thus, it is needed to allocate the water use as efficient as possible. To reach this target, it is needed to make a system model for the optimization. Optimization analysis would give more information for allocating the water of each objective function [HOESEIN, LIMANTARA 2010].

Agricultural sector is a key driver in the worldwide economic and social development. It plays a substantial role in achieving, among other, food security, economic diversification, poverty eradication, and human welfare. Its role is highly emphasized while the international community, in particular developing countries, is struggling to cope with the impacts of the climate change and the implementation of response measures in a sustainable manner. The adjustment of planting dates and crop variety, and crop re-allocation are among the selected planned adaptation actions in the agricultural sector [IPCC 2007]. Due to the rapid change in population and urbanization, land and water resources are becoming very limited. Subsequently, crop optimization has received extensive attention in recent years and mathematical models have been developed to determine the optimal use of the available resources for maximizing the net benefits subjected to some constraints [ABDULKADER et al. 2012].

The various modelling approaches have been applied to optimize the cropping pattern worldwide including the linear and nonlinear optimization models [HAOUARI, AZAIEZ 2001; KAUR et al. 2010; MONTAZAR, RAHIMIKOB 2008; SINGH et al. 2001], deterministic linear programming and chance-constrained linear programming models [SETHI et al. 2006], the interactive fuzzy multi-objective optimization approach [ZHOU et al. 2007], the goal program approach [VIVEKANADAN et al. 2009], the multi-objective fractious. The various techniques for optimization have been developed for making the most efficient use of the available resources. Among these different models, linear programming has been found to be one of the best and simple techniques for optimizing an irrigated area where various crops are competing for a limited quantity of land and water resources [OSAMA et al. 2017].

Parsanga has the area irrigation of 500 ha. Irrigation network of Parsanga is located in the authority area of the Water Resource General Work Institution of Sumenep Regency. The problem is there is deviation of the cropping pattern balance due to the less attention of water availability. Therefore, it is directly happened the waste of water use which causes the wild tapping anywhere [PRIYANTORO, LIMANTARA 2011]. Based on the problem as above, it is seen necessary to carry out the optimization of agricultural area for improving the agricultural system in recent year by optimizing the area and the available water discharge. Besides that, it is hoped to produce the maximal agricultural product benefit.

\section{MATERIALS AND METHOD}

The irrigation network of Parsanga is located in the catchment area of Anjuk River. However, administratively, it is located in the 3 district areas which

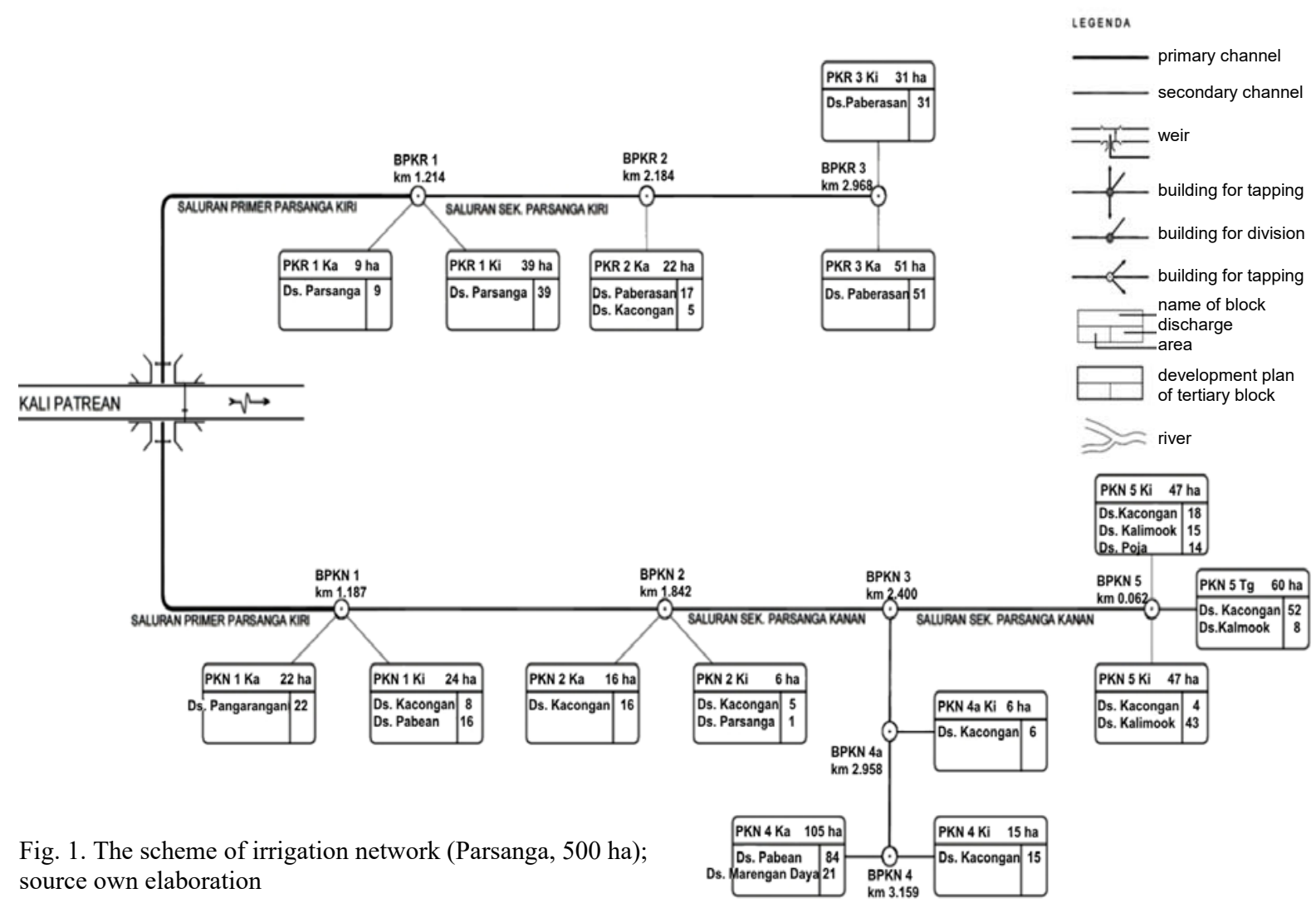


consist of 8 villages. The irrigation area is 500 ha and the scheme of irrigation network is presented as in the Figure 1.

Figure 2 presents the map of rainfall stations. There are 4 rainfall stations in the Parsanga watershed such as the rainfall stations of Parsanga, Sumenep city, Kebonagung, and Manding.

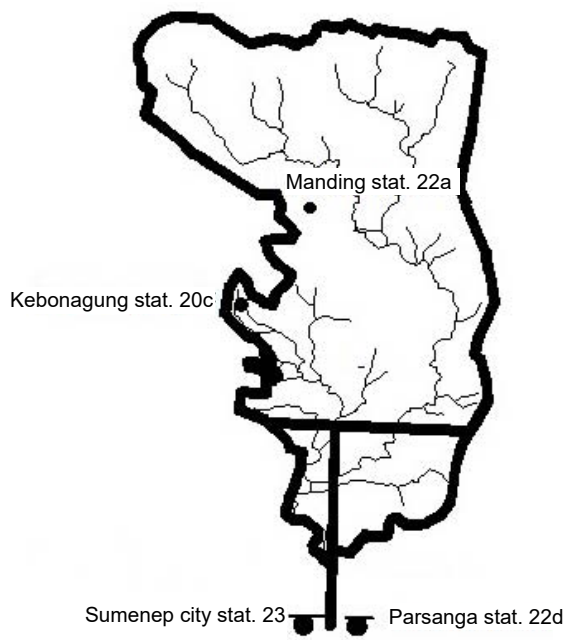

Fig. 2. Map of rainfall station; source: own elaboration

The methodology in this study consists of the analysis of rainfall, discharge, crop water requirement, irrigation water requirement, water need at intake, water balance for determining the available discharge that can fulfil the need or not; and the optimization of cropping pattern. The optimization of water allocation on the tertiary plot is carried out by using the Linear Programming with the objective function is to maximize the production yield and the constraints are the water availability and irrigation water requirement. Type of discharge which is used in this study is the dependable discharge of $80 \%$ which is as one of the constraints. However, cropping pattern means as a schedule with terms of cropping. Each cropping pattern consists of three cropping periods that mentions as the cropping season. Due to the discharge constraint, there is carried out the optimization analysis with the scenario of 4 cropping pattern as follow:

1) existing cropping pattern: paddy - paddy/second crop - paddy/second crop (It means that in the cropping season I is cropped paddy, in the cropping season II is cropped paddy and second crop, and in the cropping season III is cropped paddy and second crop);

2) proposition-1 cropping pattern: paddy (cropping season I) - paddy (cropping season II) - paddy/ second crop (cropping season III);

3) proposition-3 cropping pattern: paddy/second crop (cropping season I) - paddy/second crop (cropping season II) - second crop (cropping season III);

4) proposition-3 cropping pattern: paddy/second crop (cropping season I) - second crop (cropping season II) - paddy/second crop (cropping season III).

\section{IRRIGATION WATER REQUIREMENT}

Irrigation water requirement is an amount of water which is needed by the crop on the optimal growth condition without water deficiency and it is expressed as the net from requirement (NFR). NFR means as the net water requirement for irrigation.

\section{WATER BALANCE METHOD}

Irrigation water requirement (on the rice field) is as follow:

a) for paddy:

$$
N F R=C u+P d+N R+P-R_{\mathrm{eff}}
$$

b) for the second crop:

$$
N F R=C u+P-R_{\text {eff }}
$$

Where: $N F R=$ water need on the rice field $\left(1 \mathrm{~mm} \cdot \mathrm{day}^{-1} \cdot 10,000 /(24 \cdot 60 \cdot 60)=0.11 \mathrm{dm}^{3} \cdot \mathrm{s}^{-1} \cdot \mathrm{ha}^{-1}\right)$; $C u=$ crop water requirement $\left(\mathrm{mm} \cdot\right.$ day $\left.^{-1}\right) ; P d=$ water need for land processing $\left(\mathrm{mm} \cdot \mathrm{day}^{-1}\right) ; N R=$ water need for nursery $\left(\mathrm{mm} \cdot\right.$ day $\left.^{-1}\right) ; P=$ percolation $\left(\mathrm{mm} \cdot \mathrm{day}^{-1}\right) ; R_{\mathrm{eff}}=$ effective rainfall $\left(\mathrm{mm} \cdot \mathrm{day}^{-1}\right)$.

\section{CROPPING PATTERN}

Cropping pattern is an activity of regulating time, place, type, and crop area in the irrigation area. However, the aim of cropping pattern is to make the use of irrigation water availability as efficient as possible so the crop can well grow.

\section{DEPENDABLE DISCHARGE}

The fulfilled possibility is determined in amount of $80 \%$. It means that the possibility of river discharge under the dependable discharge is $20 \%$. The dependable discharge in this study is analysed for half monthly period. The average discharge of river is analysed based on the data of daily river discharge. The procedure of dependable discharge analysis is as follow [LIMANTARA 2010c]:

1) to analyse the average of discharge every year;

2) to rank the data from the biggest to the smallest one;

3) to analyse the probability of each data by using the formula of Weibull as follow [LIMANTARA 2010c]:

$$
p=\frac{m}{n+1} 100 \%
$$

Where: $p=$ probability $(\%) ; m=$ number of discharge data; $n=$ the amount of data.

\section{OPTIMIZATION}

This study uses the method of linear programming. It is based on the consideration that Linear Programming is simple enough on the formulation as well as the stage of solving, so it does not need the 
difficult solving level [LIMANTARA 2007; LIMANTARA, SOETOPO 2011]. The selection of the method is due to the use of Linear Programming which has the some advantages as follow [LIMANTARA 2010b; 2011]: 1) this method can be used for solving a system with many enough of variables and constraints; 2 ) the using of this method is easy and in addition it is supported by the many program packages that have been circulated; 3) the mathematical functions are simple; and 4) the result is good enough.

\section{LINEAR PROGRAMMING}

Decision variable is as the variable which will be found and giving the best value for the aim that will be reached. However, objective function is a mathematical function which has to be maximized or minimized and it reflects the aim that will be reached [LIMANTARA, SOETOPO 2011]. The mathematical model of linear programming is as follow:

$$
\max Z=\sum_{n=1}^{n} c_{n} x_{n}
$$

Where: $Z$ = objective function (in this study is to maximize the benefit of agricultural yield) (Rp); $c_{n}=$ net benefit of rice field yield $\left(\mathrm{Rp} \cdot \mathrm{ha}^{-1}\right) ; x_{n}=$ irrigation area (ha).

Constraint is as a mathematical function which becomes as the constraint for making effort to maximize or minimize the objective function and it represents the constraint which has to be reached.

\section{CONSTRAINT OF DISCHARGE VOLUME}

$$
\sum_{n=1}^{n} a_{m n} x_{n} \leq b_{m}
$$

and

$$
x_{n} \geq 0
$$

Where: $x_{n}=$ variable (in this study is the irrigation area) (ha); $a_{m n}=$ constant (in this study is the volume of irrigation water requirement) $\left(\mathrm{m}^{3} \cdot \mathrm{ha}^{-1}\right) ; b_{m}=$ volume of the water availability $\left(\mathrm{m}^{3}\right) ; c_{n}=$ net benefit of the irrigated area/rice field $\left(\mathrm{Rp} \cdot \mathrm{ha}^{-1}\right) ; m=$ the amount of constraint; $n=$ the amount of decision variable.

\section{CONSTRAINT OF AREA}

$$
X_{1}+X_{2} \leq X_{m}
$$

Where: $X_{1}=$ area of the rice field (ha); $X_{2}=$ area of the second crop field (ha); $X_{m}=$ the available area (ha).

\section{RESULTS AND DISCUSSION}

\section{ANALYSIS OF RAINFALL DATA}

The evaluation of data accuracy and the relation among the stations is carried out by using the consistency test based on the double mass curve. This method is comparing the yearly rainfall cumulative from one station with the average of the other stations on the same year [LIMANTARA 2010c]. For example, the consistency test for the rainfall station 1 (Parsanga) is compared to the average cumulative of the other three rainfall stations (Sumenep city, Kebonagung, Manding) and it is presented in the Figure 3. There are also carried out each for the other 3 rainfall stations with the same procedure.

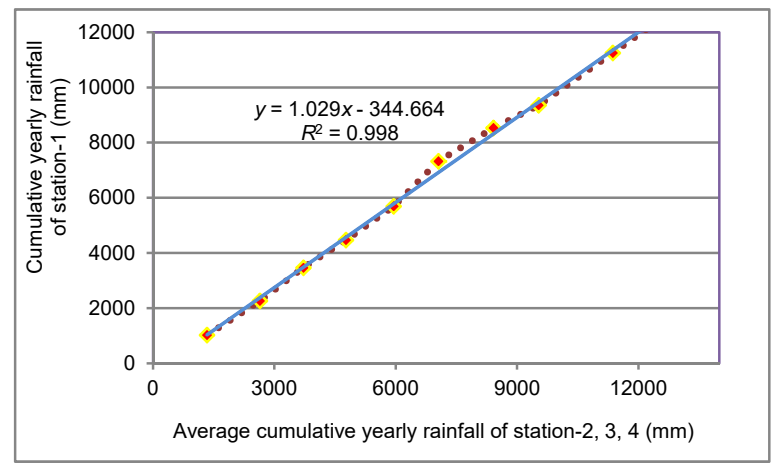

Fig. 3. The relation between cumulative yearly rainfall from rainfall station-1 (Parsanga) to the average cumulative rainfall from rainfall station-2,3,4 (Sumenep city, Kebonagung, and Mading); source: own study

The accuracy of data and the relation among the stations can be seen from the value of determination coefficient. If the determination coefficient is increasingly close to $100 \%$, so the data of every station is assumed accurate and it is related with the other station. The result of consistency test is presented as in the Table 1.

Table 1. Consistency test of rainfall data on 2004 until 2013

\begin{tabular}{|l|c|c|c|}
\hline \multirow{2}{*}{ Name of station } & \multicolumn{2}{|c|}{ Number of } & Determination \\
\cline { 2 - 3 } & station & test station & coefficient \\
\hline Parsanga & $22 \mathrm{~d}$ & station-1 & 0.994 \\
\hline Sumenep city & 23 & station-2 & 0.998 \\
\hline Kebonagung & $20 \mathrm{c}$ & station-3 & 0.996 \\
\hline Manding & $22 \mathrm{a}$ & station-4 & 0.997 \\
\hline
\end{tabular}

Explanations: stations' numbers as in Fig. 2.

Source: own study.

The dependable and effective rainfall are analysed based on the 10 daily rainfall of the average monthly rainfall during the last 10 years (from 2004 until 2013) from the 4 rainfall stations as mentioned above. The effective rainfall is analysed by using the basic year method which the steps as follow:

1) the yearly rainfall during 10 years are sorted from small to large.

2 ) to analyse $R_{80}$ for paddy and $R_{50}$ for the second crop with the formula as follow:

$$
\begin{aligned}
& R_{80}=\frac{n}{5}+1=\frac{10}{5}+1=3 \\
& R_{50}=\frac{n}{2}+1=\frac{10}{2}+1=6
\end{aligned}
$$

3 ) based on the result, there is determined the basic year of using the rainfall data for paddy and the 
second crop, as presented in the Table 2; for paddy is used the $3^{\text {rd }}$ rank of the year such as $2005\left(R_{80}\right)$ and for the second crop is used the $6^{\text {th }}$ rank of the year such as $2011\left(R_{50}\right)$.

The effective rainfall for paddy is determined by $70 \%$ of dependable rainfall of $80 \%\left(R_{80}\right)$. However, for the second crop, it is analysed based on the actual evapotranspiration, rainfall, and water availability which can be used by the crop and it is based on the root depth. Analysis result of the dependable and effective rainfall is presented as in the Tables 2 and 3.

Table 2. Dependable rainfall

\begin{tabular}{|c|c|c|c|c|c|c|}
\hline \multicolumn{3}{|c|}{ Data of rainfall } & \multicolumn{3}{|c|}{ Rank of data } & \multirow[b]{2}{*}{ Note } \\
\hline No & year & $\begin{array}{c}\text { rainfall } \\
\mathrm{mm}\end{array}$ & No & year & $\begin{array}{c}\text { rainfall } \\
\mathrm{mm}\end{array}$ & \\
\hline 1 & 2004 & 1,073 & 1 & 2012 & 825 & - \\
\hline 2 & 2005 & 1,019 & 2 & 2008 & 1,003 & - \\
\hline 3 & 2006 & 1,239 & 3 & 2005 & 1,019 & $R_{80}$ \\
\hline 4 & 2007 & 1,202 & 4 & 2004 & 1,073 & - \\
\hline 5 & 2008 & 1,003 & 5 & 2007 & 1,202 & - \\
\hline 6 & 2009 & 1,223 & 6 & 2011 & 1,203 & $R_{50}$ \\
\hline 7 & 2010 & 1,615 & 7 & 2009 & 1,223 & - \\
\hline 8 & 2011 & 1,203 & 8 & 2006 & 1,239 & - \\
\hline 9 & 2012 & 825 & 9 & 2010 & 1,635 & - \\
\hline 10 & 2013 & 1,901 & 10 & 2013 & 1,901 & - \\
\hline
\end{tabular}

Source: own study.

\section{ANALYSIS OF POTENTIAL EVAPOTRANSPIRATION}

After obtaining the dependable and effective rainfall, then it is continued by analysing the potential evapotranspiration by using the Penman method. The climate data which is used is from 2004 until 2013 and the result is presented as in the Table 4.

The dependable discharge is analysed by using Weibull formula with the steps are as follow:

1) to analyse the average discharge for every year;

2) to rank the data from small to large;

3) to analyse the probability of each data with the Weibull formula as follow (for example for discharge data on 2014 as in the Table 5);

$p=\frac{m}{N+1} 100 \%=\frac{1}{10+1} 100 \%=9.09 \%$ etc. for the other data

Where: $p=$ probability $(\%) ; m=$ the serial number of data; $N=$ the amount of data.

Table 5 presents the probability of discharge data from 2004 until 2013 with the Weibull formula.
Table 3. Analysis of dependable rainfall $\left(R_{80}\right)$ and effective rainfall $\left(R_{\text {eff }}\right)$

\begin{tabular}{|c|c|c|c|c|c|c|}
\hline \multirow{2}{*}{ Month } & \multirow{2}{*}{ Period } & \multirow{2}{*}{$\begin{array}{l}R_{80} \\
\mathrm{~mm}\end{array}$} & \multicolumn{2}{|c|}{$R_{\text {eff }}$-paddy } & \multicolumn{2}{|c|}{$R_{\text {eff }}$-second crop } \\
\hline & & & $\mathrm{mm}$ & $\mathrm{mm} \cdot \mathrm{day}^{-1}$ & $\mathrm{~mm}$ & $\mathrm{~mm} \cdot \mathrm{day}^{-1}$ \\
\hline \multirow{3}{*}{ Jan } & 1 & 138.0 & 96.6 & 9.66 & 39.230 & 3.92 \\
\hline & 2 & 62.0 & 43.4 & 4.34 & 17.608 & 1.76 \\
\hline & 3 & 51.0 & 35.7 & 3.57 & 14.484 & 1.45 \\
\hline \multirow{3}{*}{ Feb } & 1 & 74.0 & 51.8 & 5.18 & 21.016 & 2.10 \\
\hline & 2 & 49.0 & 34.3 & 3.43 & 13.916 & 1.39 \\
\hline & 3 & 32.0 & 22.4 & 2.24 & 9.088 & 0.91 \\
\hline \multirow{3}{*}{ Mar } & 1 & 112.0 & 78.4 & 7.84 & 31.808 & 3.18 \\
\hline & 2 & 10.0 & 7.0 & 0.70 & 2.840 & 0.28 \\
\hline & 3 & 30.0 & 21.0 & 2.10 & 8.520 & 0.85 \\
\hline \multirow{3}{*}{ Apr } & 1 & 14.0 & 9.8 & 0.98 & 3.976 & 0.40 \\
\hline & 2 & 123.0 & 86.1 & 8.61 & 34.932 & 3.49 \\
\hline & 3 & 0.0 & 0.0 & 9.00 & 0.0 & 0.0 \\
\hline \multirow{3}{*}{ May } & 1 & 0.0 & 0.0 & 0.0 & 0.0 & 0.0 \\
\hline & 2 & 0.0 & 0.0 & 0.0 & 0.0 & 0.0 \\
\hline & 3 & 0.0 & 0.0 & 0.0 & 0.0 & 0.0 \\
\hline \multirow{3}{*}{ Jun } & 1 & 0.0 & 0.0 & 0.0 & 0.0 & 0.0 \\
\hline & 2 & 0.0 & 0.0 & 0.0 & 0.0 & 0.0 \\
\hline & 3 & 0.0 & 0.0 & 0.0 & 0.0 & 0.0 \\
\hline \multirow{3}{*}{ Jul } & 1 & 0.0 & 0.0 & 0.0 & 0.0 & 0.0 \\
\hline & 2 & 0.0 & 0.0 & 0.0 & 0.0 & 0.0 \\
\hline & 3 & 0.0 & 0.0 & 0.0 & 0.0 & 0.0 \\
\hline \multirow{3}{*}{ Aug } & 1 & 0.0 & 0.0 & 0.0 & 0.0 & 0.0 \\
\hline & 2 & 0.0 & 0.0 & 0.0 & 0.0 & 0.0 \\
\hline & 3 & 0.0 & 0.0 & 0.0 & 0.0 & 0.0 \\
\hline \multirow{3}{*}{ Sep } & 1 & 0.0 & 0.0 & 0.0 & 0.0 & 0.0 \\
\hline & 2 & 0.0 & 0.0 & 0.0 & 0.0 & 0.0 \\
\hline & 3 & 0.0 & 0.0 & 0.0 & 0.0 & 0.0 \\
\hline \multirow{3}{*}{ Oct } & 1 & 0.0 & 0.0 & 0.0 & 0.0 & 0.0 \\
\hline & 2 & 0.0 & 0.0 & 0.0 & 0.0 & 0.0 \\
\hline & 3 & 0.0 & 0.0 & 0.0 & 0.0 & 0.0 \\
\hline \multirow{3}{*}{ Nov } & 1 & 0.0 & 0.0 & 0.0 & 0.0 & 0.0 \\
\hline & 2 & 0.0 & 0.0 & 0.0 & 0.0 & 0.0 \\
\hline & 3 & 25.0 & 17.5 & 1.75 & 7.100 & 0.71 \\
\hline \multirow{3}{*}{ Dec } & 1 & 66.0 & 46.2 & 4.62 & 18.744 & 1.87 \\
\hline & 2 & 103.0 & 72.1 & 7.21 & 29.252 & 2.93 \\
\hline & 3 & 130.0 & 91.0 & 9.10 & 36.920 & 3.69 \\
\hline \multicolumn{2}{|c|}{ Total } & 1019.0 & 713.3 & 71.33 & 289.434 & 28.94 \\
\hline
\end{tabular}

Source: own study.

Water from the Parsanga Dam is intended for irrigating the agricultural area in the Parsanga. Based on the analysis as in the Table 5 by using the Weibull formula, the probability of $80 \%$ is happened on the 2010, so the discharge data on the 2010 will be used for analysing the dependable discharge in the Parsanga. Table 6 presents the dependable discharge and discharge on 2010 in the Parsanga.

Analysis of water requirement for the land preparation is carried out by using the method of Van De Gor and the result is presented in the Table 7.

Table 4. Results of the evapotranspiration analysis by using the Penman method

\begin{tabular}{|c|c|c|c|c|c|c|c|c|c|c|c|c|c|}
\hline \multirow{2}{*}{ Item } & \multirow{2}{*}{ Unit } & \multicolumn{12}{|c|}{ Month } \\
\hline & & Jan & Feb & Mar & Apr & May & Jun & Jul & Aug & Sep & Oct & Nov & Dec \\
\hline Temperature $(T)$ & ${ }^{\circ} \mathrm{C}$ & 27.3 & 27.2 & 27.9 & 28.4 & 27.9 & 28.1 & 27.5 & 27.6 & 28.6 & 29.3 & 29.2 & 28.4 \\
\hline Wind velocity $(u)$ & $\mathrm{m} \cdot \mathrm{s}^{-1}$ & 3.60 & 3.60 & 1.54 & 2.06 & 2.06 & 3.0 & 4.12 & 4.12 & 3.60 & 3.70 & 2.93 & 1.70 \\
\hline Relative humidity $(R h)$ & $\%$ & 88.0 & 87.0 & 87.0 & 86.0 & 87.0 & 83.3 & 79.0 & 79.0 & 78.0 & 79.0 & 81.0 & 85.0 \\
\hline Sun brightness $(n: N)$ & $\%$ & 65.0 & 56.0 & 77.0 & 79.0 & 76.0 & 80.9 & 89.0 & 100 & 100 & 99.0 & 88.0 & 61.0 \\
\hline Evapotranspiration & $\mathrm{mm} \cdot$ day $^{-1}$ & 6.26 & 5.92 & 5.61 & 5.02 & 4.44 & 4.68 & 5.57 & 6.84 & 8.28 & 8.64 & 7.80 & 5.82 \\
\hline
\end{tabular}

Explanations: $n=$ time of real sun brightness in a day (hour), $N=$ potential time of sun brightness in a day (12 hours).

Source: own study. 
Table 5. The probability of discharge data from 2004 until 2013 with the Weibull formula

\begin{tabular}{|c|c|c|c|c|c|c|c|}
\hline \multicolumn{3}{|c|}{ Data of discharge $Q$} & \multicolumn{3}{|c|}{ Rank of data } & \multirow[b]{2}{*}{$\begin{array}{c}p \\
\%\end{array}$} & \multirow[b]{2}{*}{ Result } \\
\hline No & year & $\begin{array}{c}Q \\
\mathrm{~m}^{3} \cdot \mathrm{s}^{-1}\end{array}$ & No & year & $\begin{array}{c}Q \\
\mathrm{~m}^{3} \cdot \mathrm{s}^{-1}\end{array}$ & & \\
\hline 1 & 2004 & 0.188 & 1 & 2004 & 0.188 & 9.09 & - \\
\hline 2 & 2005 & 0.329 & 2 & 2005 & 0.329 & 18.18 & - \\
\hline 3 & 2006 & 0.506 & 3 & 2009 & 0.438 & 27.27 & - \\
\hline 4 & 2007 & 0.468 & 4 & 2007 & 0.468 & 36.36 & - \\
\hline 5 & 2008 & 0.473 & 5 & 2008 & 0.473 & 45.45 & - \\
\hline 6 & 2009 & 0.438 & 6 & 2006 & 0.506 & 54.55 & - \\
\hline 7 & 2010 & 0.572 & 7 & 2012 & 0.523 & 63.64 & - \\
\hline 8 & 2011 & 0.547 & 8 & 2011 & 0.547 & 72.73 & - \\
\hline 9 & 2012 & 0.523 & 9 & 2010 & 0.572 & 81.82 & $Q_{80}$ \\
\hline 10 & 2013 & 1.424 & 10 & 2013 & 1.424 & 90.91 & - \\
\hline
\end{tabular}

Source: own study.

\section{ANALYSIS OF IRRIGATION BENEFIT}

Based on the existing cropping pattern, there are obtained the crop, rice field, and the intake water requirement. The water balance based on the dependable discharge of $80 \%$ is presented in the Figure 4 . It is seen that there is the water deficit in several month, so it is needed to be carried out the optimization of water allocation. The recapitulation of total water irrigation is presented in the Table 8 and the benefit of irrigation per ha is presented in the Table 9.

Table 10 presents the volume of available water in the Sentong secondary channel and Table 11 presents the irrigation water requirements. The two analysis results are needed for the input in the optimization analysis.
Table 6. The dependable discharge $\left(Q_{\text {dependable }}\right)$ and discharge on 2010 in the Parsanga $\left(Q_{2010}\right)$

\begin{tabular}{|c|c|c|c|}
\hline Month & Period & $\begin{array}{l}Q_{2010} \\
\mathrm{~m}^{3} \cdot \mathrm{s}^{-1}\end{array}$ & $\begin{array}{c}Q_{\text {dependable }} \\
\mathrm{m}^{3} \cdot \mathrm{s}^{-1}\end{array}$ \\
\hline \multirow{3}{*}{ Dec } & 1 & 0.10 & 0.10 \\
\hline & 2 & 0.94 & 0.94 \\
\hline & 3 & 1.34 & 1.34 \\
\hline \multirow{3}{*}{ Jan } & 1 & 0.94 & 0.94 \\
\hline & 2 & 1.28 & 1.28 \\
\hline & 3 & 1.44 & 1.44 \\
\hline \multirow{3}{*}{ Feb } & 1 & 1.28 & 1.28 \\
\hline & 2 & 1.28 & 1.28 \\
\hline & 3 & 1.28 & 1.28 \\
\hline \multirow{3}{*}{ Mar } & 1 & 1.28 & 1.28 \\
\hline & 2 & 1.30 & 1.30 \\
\hline & 3 & 1.30 & 1.30 \\
\hline \multirow{3}{*}{ Apr } & 1 & 1.28 & 1.28 \\
\hline & 2 & 0.71 & 0.71 \\
\hline & 3 & 0.37 & 0.37 \\
\hline \multirow{3}{*}{ May } & 1 & 0.17 & 0.17 \\
\hline & 2 & 0.10 & 0.10 \\
\hline & 3 & 0.27 & 0.27 \\
\hline \multirow{3}{*}{ Jun } & 1 & 0.31 & 0.31 \\
\hline & 2 & 0.37 & 0.37 \\
\hline & 3 & 0.37 & 0.37 \\
\hline \multirow{3}{*}{ Jul } & 1 & 0.37 & 0.37 \\
\hline & 2 & 0.37 & 0.37 \\
\hline & 3 & 0.37 & 0.37 \\
\hline \multirow{3}{*}{ Aug } & 1 & 0.27 & 0.27 \\
\hline & 2 & 0.27 & 0.27 \\
\hline & 3 & 0.14 & 0.14 \\
\hline \multirow{3}{*}{ Sep } & 1 & 0.12 & 0.12 \\
\hline & 2 & 0.12 & 0.12 \\
\hline & 3 & 0.12 & 0.12 \\
\hline \multirow{3}{*}{ Oct } & 1 & 0.12 & 0.12 \\
\hline & 2 & 0.12 & 0.12 \\
\hline & 3 & 0.12 & 0.12 \\
\hline \multirow{3}{*}{ Nov } & 1 & 0.12 & 0.12 \\
\hline & 2 & 0.12 & 0.12 \\
\hline & 3 & 0.12 & 0.12 \\
\hline
\end{tabular}

Source: own study.

Table 7. Analysis of water need for the land preparation by using the method of Van De Gor and Zijlstra (2004-2013)

\begin{tabular}{|c|c|c|c|c|c|c|c|c|c|c|c|c|c|}
\hline \multirow{2}{*}{ Parameter } & \multirow{2}{*}{ Unit } & \multicolumn{12}{|c|}{ Value in the month } \\
\hline & & Jan & Feb & Mar & Apr & May & Jun & Jul & Aug & Sep & Oct & Nov & Dec \\
\hline$E T_{o}$ & $\mathrm{~mm} \cdot \mathrm{day}^{-1}$ & 6.257 & 5.924 & 5.607 & 5.024 & 4.439 & 4.681 & 5.572 & 6.835 & 8.278 & 8.639 & 7.800 & 5.817 \\
\hline$E_{o}=E T_{o} \cdot 1.1$ & $\mathrm{~mm} \cdot$ day $^{-1}$ & 6.883 & 6.516 & 6.168 & 5.527 & 4.883 & 5.149 & 6.129 & 7.519 & 9.106 & 9.502 & 8.580 & 6.399 \\
\hline$P$ & $\mathrm{~mm} \cdot \mathrm{day}^{-1}$ & 2.0 & 2.0 & 2.0 & 2.0 & 2.0 & 2.0 & 2.0 & 2.0 & 2.0 & 2.0 & 2.0 & 2.0 \\
\hline$M=E_{o}+P$ & $\mathrm{~mm} \cdot$ day $^{-1}$ & 8.883 & 8.516 & 8.168 & 7.527 & 6.883 & 7.149 & 8.129 & 9.519 & 11.106 & 11.592 & 10.580 & 8.399 \\
\hline$t$ & day & 31 & 29 & 31 & 30 & 31 & 30 & 31 & 31 & 30 & 31 & 30 & 31 \\
\hline$S$ & $\mathrm{~mm}$ & 300.0 & 300.0 & 300.0 & 300.0 & 300.0 & 300.0 & 300.0 & 300.0 & 300.0 & 300.0 & 300.0 & 300.0 \\
\hline$k=(M \cdot t) / S$ & - & 0.918 & 0.823 & 0.844 & 0.753 & 0.711 & 0.715 & 0.840 & 0.984 & 1.111 & 1.189 & 1.058 & 0.868 \\
\hline$L P=M e^{k} /\left(e^{k}-1\right)$ & $\mathrm{mm} \cdot$ day $^{-1}$ & 14.789 & 15.181 & 14.329 & 14.231 & 13.524 & 13.997 & 14.305 & 15.205 & 16.560 & 16.542 & 16.206 & 14.477 \\
\hline Water need & $\mathrm{dm}^{3} \cdot \mathrm{s}^{-1} \mathrm{ha}^{-1}$ & 1.712 & 1.757 & 1.658 & 1.647 & 1.565 & 1.620 & 1.656 & 1.760 & 1.917 & 1.915 & 1.876 & 1.676 \\
\hline
\end{tabular}

Explanations: $E T_{\mathrm{o}}=$ potential evapotranspiration, $E_{\mathrm{o}}=$ evaporation during the land preparation, $P=$ percolation, $M=$ water need for the changing water loss due to the evapotranspiration and percolation in the saturated rice field; $t=$ duration of land preparation; $S=$ the need for saturating of upper layer; $e=$ Napier's constant (2.71828); $L P=$ water need for the land processing.

Source: own study.

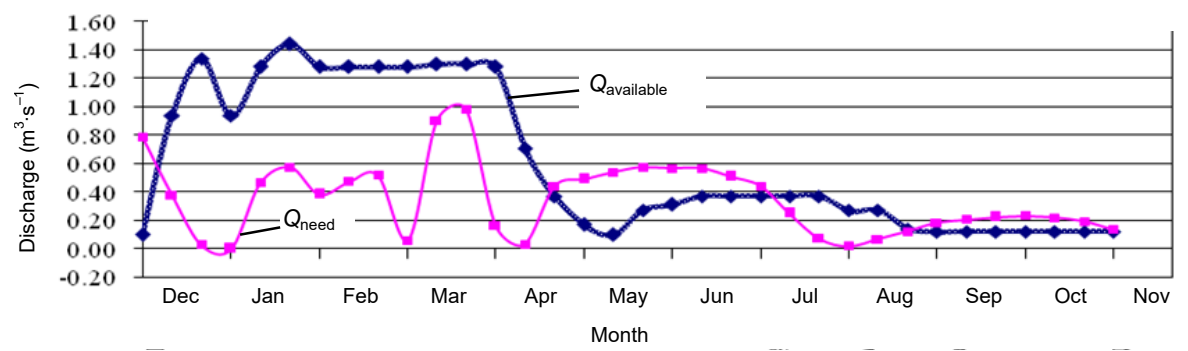

Fig. 4. Water balance based on the dependable discharge of $80 \%$; source: own study 
Table 8. Recapitulation of irrigation water total in the irrigation area of Parsanga

\begin{tabular}{|c|c|c|c|}
\hline \multirow{2}{*}{$\begin{array}{c}\text { Cropping pattern } \\
\text { (CP) }\end{array}$} & \multirow{2}{*}{$\begin{array}{c}\text { Cropping } \\
\text { season }\end{array}$} & \multicolumn{2}{|c|}{$\begin{array}{c}\text { Irrigation water requirement } \\
\mathrm{dm}^{3} \cdot \mathrm{s}^{-1} \cdot \mathrm{ha}^{-1}\end{array}$} \\
\cline { 3 - 4 } & & paddy & second crop \\
\hline \multirow{3}{*}{ Existing CP } & I & 7.216 & 0.000 \\
& II & 9.184 & 5.522 \\
& III & 0.000 & 8.513 \\
\hline \multirow{3}{*}{ Proposition-1 CP } & I & 5.030 & 0.000 \\
& II & 0.000 & 0.000 \\
& III & 14.044 & 8.513 \\
\hline \multirow{3}{*}{ Proposition-2 CP } & I & 7.216 & 3.835 \\
& II & 9.184 & 5.552 \\
& III & 0.000 & 8.513 \\
\hline \multirow{2}{*}{ Proposition-3 CP } & I & 7.216 & 0.000 \\
& II & 0.000 & 0.000 \\
& III & 16.077 & 8.513 \\
\hline
\end{tabular}

Source: own study.

Table 9. Net benefit of rice field per ha

\begin{tabular}{|c|c|c|c|c|c|}
\hline \multirow{2}{*}{$\begin{array}{l}\text { Type of } \\
\text { crop }\end{array}$} & \multirow{2}{*}{$\begin{array}{l}\text { Yield } \\
\mathrm{t} \cdot \mathrm{ha}^{-1}\end{array}$} & \multirow{2}{*}{ 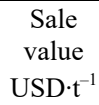 } & Total & $\begin{array}{c}\text { Production } \\
\text { cost }\end{array}$ & Benefit \\
\hline & & & \multicolumn{3}{|c|}{$\mathrm{USD} \cdot \mathrm{ha}^{-1}$} \\
\hline \begin{tabular}{|l|} 
Paddy \\
\end{tabular} & 5 & 295.26 & $1,476.30$ & 269.50 & $1,206.80$ \\
\hline Second crop & 3 & 295.26 & 885.78 & 216.72 & 669.06 \\
\hline
\end{tabular}

Explanations: this net benefit of rice field per ha is suitable for the existing cropping pattern, and the proposition-1, $-2,-3$ of cropping pattern.

Source: own study

Table 10. The volume of available water $\left(Q_{2010}\right)$ in the Sentong secondary channel

\begin{tabular}{|c|c|c|c|}
\hline \multirow{2}{*}{$\begin{array}{c}\text { Dependable discharge } \\
\text { in irrigation area of Parsanga }\end{array}$} & \multicolumn{3}{|c|}{ Water volume } \\
\cline { 2 - 4 } & $\cdot 10^{6} \mathrm{~m}^{3}$ in cropping season \\
\hline Dependable discharge of $80 \%$ & 1.568 & 1.505 & 1.061 \\
\hline
\end{tabular}

Explanations: the volume of available water $\left(Q_{2010}\right)$ in the Sentong secondary channel is available for the existing cropping pattern, and the proposition-1, $-2,-3$ of cropping pattern.

Source: own study.

Table 11. Irrigation water requirements

\begin{tabular}{|l|c|r|r|}
\hline \multirow{2}{*}{$\begin{array}{c}\text { Cropping pattern } \\
\text { (CP) in irrigation } \\
\text { area of Parsanga }\end{array}$} & \multirow{2}{*}{$\begin{array}{c}\text { Cropping } \\
\text { season }\end{array}$} & \multicolumn{2}{|c|}{$\begin{array}{r}\text { Water requirement } \\
\mathrm{m}^{3} \cdot \mathrm{ha}^{-1}\end{array}$} \\
\cline { 3 - 4 } Existing CP & I & 574.637 & 0.000 \\
& II & $1,048.142$ & 532.305 \\
& III & $1,258.165$ & 681.864 \\
\hline \multirow{3}{*}{ Proposition-1 CP } & I & 574.637 & 0.000 \\
& II & $1,048.142$ & 0.000 \\
& III & $1,258.165$ & 681.864 \\
\hline & I & 574.637 & 184.854 \\
Proposition-2 CP & II & 862.841 & 532.205 \\
& III & 0.000 & 681.684 \\
\hline \multirow{2}{*}{ Proposition-3 CP } & I & 424.733 & 184.854 \\
& II & 0 & 532.205 \\
& III & $1,258.165$ & 681.864 \\
\hline
\end{tabular}

Source: own study.

\section{ANALYSIS OF OPTIMIZATION}

Table 12 presents the benefit per ha for paddy and the second crop.
Table 12. Benefit per ha for paddy and the second crop

\begin{tabular}{|c|c|c|}
\hline \multirow{2}{*}{ Cropping season } & \multicolumn{2}{|c|}{ Benefit (USD·ha $^{-1}$ ) } \\
\cline { 2 - 3 } & paddy & second crop \\
\hline I, II, III & 757.99 & 213.13 \\
\hline
\end{tabular}

Source: own study.

Explanation for objective function: $Z=$ benefit of paddy $\left(\mathrm{USD} \cdot \mathrm{ha}^{-1}\right) \cdot$ area of paddy $\left(X_{n}, \mathrm{ha}\right)+$ benefit of second crop (USD $\cdot \mathrm{ha}^{-1} \cdot$ area of second crop $\left(X_{n}\right.$, ha)

Objective function for cropping seasons:

$$
Z=757.99\left(\sum_{n=1}^{15} X_{n}\right)+213.13\left(\sum_{n=16}^{30} X_{n}\right)
$$

Table 13 presents the list of variables which are used in the optimization model and Table 14 presents the list of each irrigation area in the Parsanga.

Table 13. List of variables used in the optimization model

\begin{tabular}{|c|c|c|c|}
\hline No & Area's kind & Irrigation area' & Variable \\
\hline 1 & paddy & PKR-1 ka & $X_{1}$ \\
\hline 2 & paddy & PKR-1 ki & $X_{2}$ \\
\hline 3 & paddy & PKR-2 ka & $X_{3}$ \\
\hline 4 & paddy & PKR-3 ka & $X_{4}$ \\
\hline 5 & paddy & PKR-3 ki & $X_{5}$ \\
\hline 6 & paddy & PKN-1 ka & $X_{6}$ \\
\hline 7 & paddy & PKN-1 ki & $X_{7}$ \\
\hline 8 & paddy & PKN-2 ka & $X_{8}$ \\
\hline 9 & paddy & PKN-2 ki & $X_{9}$ \\
\hline 10 & paddy & PKN-4 ka & $X_{10}$ \\
\hline 11 & paddy & PKN-4 ki & $X_{11}$ \\
\hline 12 & paddy & PKN-4a ki & $X_{12}$ \\
\hline 13 & paddy & PKN-5 ka & $X_{13}$ \\
\hline 14 & paddy & PKN-5 ki & $X_{14}$ \\
\hline 15 & paddy & PKN-5 tg & $X_{15}$ \\
\hline 16 & second crop & PKR-1 ka & $X_{16}$ \\
\hline 17 & second crop & PKR-1 ki & $X_{17}$ \\
\hline 18 & second crop & PKR-2 ka & $X_{18}$ \\
\hline 19 & second crop & PKR-3 ka & $X_{19}$ \\
\hline 20 & second crop & PKR-3 ki & $X_{20}$ \\
\hline 21 & second crop & PKN-1 ka & $X_{21}$ \\
\hline 22 & second crop & PKN-1 ki & $X_{22}$ \\
\hline 23 & second crop & PKN-2 ka & $X_{23}$ \\
\hline 24 & second crop & PKN-2 ki & $X_{24}$ \\
\hline 25 & second crop & PKN-4 ka & $X_{25}$ \\
\hline 26 & second crop & PKN-4 ki & $X_{26}$ \\
\hline 27 & second crop & PKN-4a ki & $X_{27}$ \\
\hline 28 & second crop & PKN-5 ka & $X_{28}$ \\
\hline 29 & second crop & PKN-5 ki & $X_{29}$ \\
\hline 30 & second crop & PKN-5 tg & $X_{30}$ \\
\hline
\end{tabular}

Source: own study.

Table 14. List of irrigation area

\begin{tabular}{|c|c|c|}
\hline No & Irrigation area & Area, ha \\
\hline 1 & PKR-1 ka & 9 \\
\hline 2 & PKR-1 ki & 39 \\
\hline 3 & PKR-2 ka & 22 \\
\hline 4 & PKR-3 ka & 51 \\
\hline 5 & PKR-3 ki & 31 \\
\hline 6 & PKN-1 ka & 22 \\
\hline 7 & PKN-1 ki & 24 \\
\hline
\end{tabular}




\begin{tabular}{|c|c|c|}
\hline No & Irrigation area & Area, ha \\
\hline 8 & PKN-2 ka & 16 \\
\hline 9 & PKN-2 ki & 6 \\
\hline 10 & PKN-4 ka & 105 \\
\hline 11 & PKN-4 ki & 15 \\
\hline 12 & PKN-4a ki & 6 \\
\hline 13 & PKN-5 ka & 47 \\
\hline 14 & PKN-5 ki & 47 \\
\hline 15 & PKN-5 tg & 60 \\
\hline & Total & 500 \\
\hline
\end{tabular}

Explanations: codes of irrigation area as in Table 13. Source: own study.

\section{CONSTRAINT FOR IRRIGATION WATER VOLUME ON THE SECONDARY CHANNEL OF PARSANGA}

\section{Dependable discharge of $80 \%$ and for irrigation area}

The coefficients and constants of each constraint for the constraints of $\mathrm{K} 1$ until $\mathrm{K} 12$ are presented in the Table 10 and 11, however for the constraints K13 until K27 are presented in the Table 14. K1 until K12 is the constraint for available discharge (dependable discharge which is hoped can be fulfilled the irrigation requirement). However, K13 until K27 is the constraint for the irrigation area.

\section{Constraint for irrigation water volume}

Explanation:

For every cropping pattern, there are three periods of cropping season, for example: $\mathrm{K} 1, \mathrm{~K} 2$, and $\mathrm{K} 3$ are the constraint of water irrigation volume each for the first, second, and third period of cropping season. Each constraint is as follow:

- irrigation water requirement for paddy $\left(\mathrm{m}^{3} \cdot \mathrm{ha}^{-1}\right)$. area of paddy for the 15 irrigation area (number 1 until 15) (ha) + irrigation water requirement for second crop $\left(\mathrm{m}^{3} \cdot \mathrm{ha}^{-1}\right) \cdot$ area of second crop for the 15 irrigation area (number 16 until 30 (ha) $\leq$ available water volume $\left(\mathrm{m}^{3}\right)$;

- irrigation water requirement of paddy and second crop each cropping season period for each proposition of cropping pattern is presented as in the Table 11. However, the available water volume for each period of cropping season is presented as in the Table 10.

a. Existing cropping pattern

$$
\begin{gathered}
K 1=\left(574.637 \sum_{n=1}^{15} X_{n}\right)+\left(0 \sum_{n=16}^{30} X_{n}\right) \leq 1.568 \cdot 10^{6} \\
K 2=\left(1048.142 \sum_{n=1}^{15} X_{n}\right)+\left(532.305 \sum_{n=16}^{30} X_{n}\right) \leq 1.505 \cdot 10^{6} \\
K 3=\left(1258.165 \sum_{n=1}^{15} X_{n}\right)+\left(681.864 \sum_{n=16}^{30} X_{n}\right) \leq 1.061 \cdot 10^{6}
\end{gathered}
$$

b. Proposition-1 cropping pattern

$$
K 4=\left(574.637 \sum_{n=1}^{15} X_{n}\right)+\left(0 \sum_{n=16}^{30} X_{n}\right) \leq 1.568 \cdot 10^{6}
$$

$$
\begin{gathered}
K 5=\left(1048.142 \sum_{n=1}^{15} X_{n}\right)+\left(0 \sum_{n=16}^{30} X_{n}\right) \leq 1.505 \cdot 10^{6} \\
K 6=\left(1258.165 \sum_{n=1}^{15} X_{n}\right)+\left(681.864 \sum_{n=16}^{30} X_{n}\right) \leq 1.061 \cdot 10^{6}
\end{gathered}
$$

c. Proposition-2 cropping pattern

$$
\begin{gathered}
K 7=\left(574.637 \sum_{n=1}^{15} X_{n}\right)+\left(184.854 \sum_{n=16}^{30} X_{n}\right) \leq 1.568 \cdot 10^{6} \\
K 8=\left(862.841 \sum_{n=1}^{15} X_{n}\right)+\left(532.205 \sum_{n=16}^{30} X_{n}\right) \leq 1.505 \cdot 10^{6} \\
K 9=\left(0 \sum_{n=1}^{15} X_{n}\right)+\left(681.864 \sum_{n=16}^{30} X_{n}\right) \leq 1.061 \cdot 10^{6}
\end{gathered}
$$

d. Proposition-3 cropping pattern

$$
\begin{gathered}
K 10=\left(424.733 \sum_{n=1}^{15} X_{n}\right)+\left(184.854 \sum_{n=16}^{30} X_{n}\right) \leq 1.568 \cdot 10^{6} \\
K 11=\left(0 \sum_{n=1}^{15} X_{n}\right)+\left(532.205 \sum_{n=16}^{30} X_{n}\right) \leq 1.505 \cdot 10^{6} \\
K 12=\left(1258.165 \sum_{n=1}^{15} X_{n}\right)+\left(681.864 \sum_{n=16}^{30} X_{n}\right) \leq 1.061 \cdot 10^{6}
\end{gathered}
$$

\section{Constraint for irrigation area:}

Explanation for the constraint of irrigation area:

$\mathrm{Kn}$ : constraint number: area for paddy (number variable $-1,2, \ldots 15)+$ area for second crop (number variable $-16,17, \ldots 30) \leq$ available area (Tab. 14).

$K 13=X_{1}+X_{16} \leq 9$

$K 14=X_{2}+X_{17} \leq 39$

$K 15=X_{3}+X_{18} \leq 22$

$K 16=X_{4}+X_{19} \leq 51$

$K 17=X_{5}+X_{20} \leq 31$

$K 18=X_{6}+X_{21} \leq 22$

$K 19=X_{7}+X_{22} \leq 24$

$K 20=X_{8}+X_{23} \leq 16$

$K 21=X_{9}+X_{24} \leq 6$

$K 22=X_{10}+X_{25} \leq 105$

$K 23=X_{11}+X_{26} \leq 15$

$K 24=X_{12}+X_{27} \leq 6$

$K 25=X_{13}+X_{28} \leq 47$

$K 26=X_{14}+X_{29} \leq 47$

$K 27=X_{15}+X_{30} \leq 60$

The process of optimization analysis in this study is using the linear programming with the solver facility of Microsoft Excel. By inserting the parameters value of objective function and constraints, it will produce the results such as the components of variable and the value of objective function. Optimization analysis is carried out by inserting the dependable discharge of $80 \%$ and the results for each condition of cropping pattern are presented as in the Table 15. The recapitulation for optimization result for the water allocation and irrigation area is presented as in the Table 16. 
Table 15. Benefit of production yield based on the standard price of 2013 (dependable discharge is $80 \%$ )

\begin{tabular}{|c|c|c|c|c|}
\hline \multirow{2}{*}{$\begin{array}{c}\text { Cropping } \\
\text { season }\end{array}$} & \multicolumn{4}{|c|}{ Benefit of irrigation yield (USD) } \\
\cline { 2 - 5 } & existing & proposition-1 & proposition-2 & proposition-3 \\
\hline I & $603,402.14$ & $738,151.74$ & $738,151.74$ & $738,151.74$ \\
III & $374,861.14$ & $591,064.94$ & $591,064.94$ & $491,424.11$ \\
\hline Benefit & $85,639.77$ & $113,414.36$ & $113,414.36$ & $113,414.36$ \\
per year & $1,063,903.05$ & $1,442,631.04$ & $1,442,631.04$ & $1,322,990.21$ \\
\hline
\end{tabular}

Source: own study.

Table 16. Recapitulation of optimization result for the water allocation and irrigation area

\begin{tabular}{|c|c|c|c|c|}
\hline $\begin{array}{c}\text { Cropping } \\
\text { pattern }\end{array}$ & Type of crop & $\begin{array}{c}\text { Area } \\
\text { ha }\end{array}$ & $\begin{array}{c}\text { Rate of } \\
\text { irrigation } \\
Q\left(\mathrm{~m}^{3} \cdot \mathrm{ha}^{-1}\right)\end{array}$ & $\begin{array}{c}\text { Max benefit } \\
\text { USD }\end{array}$ \\
\hline \multirow{3}{*}{.$\stackrel{0}{.0}$} & $\begin{array}{l}\text { cropping season I: } \\
\text { - paddy } \\
\text { - second crop }\end{array}$ & $\begin{array}{r}500 \\
0\end{array}$ & $\begin{array}{r}500 \\
0\end{array}$ & \multirow{3}{*}{$1,063,903.05$} \\
\hline & $\begin{array}{l}\text { cropping season II: } \\
\text { - paddy } \\
\text { - second crop }\end{array}$ & $\begin{array}{r}75 \\
425\end{array}$ & $\begin{array}{r}75 \\
425\end{array}$ & \\
\hline & $\begin{array}{l}\text { cropping season III: } \\
\text { - paddy } \\
\text { - second crop }\end{array}$ & $\begin{array}{r}0 \\
125\end{array}$ & $\begin{array}{r}0 \\
125\end{array}$ & \\
\hline \multirow{3}{*}{$\begin{array}{l}\overrightarrow{1} \\
\stackrel{1}{0} \\
: \stackrel{0}{0} \\
0 \\
0 \\
0 \\
0 \\
0\end{array}$} & $\begin{array}{l}\text { cropping season I: } \\
\text { - paddy } \\
\text { - second crop }\end{array}$ & $\begin{array}{r}500 \\
0\end{array}$ & $\begin{array}{l}400 \\
100\end{array}$ & \multirow{3}{*}{$1,294,457.14$} \\
\hline & $\begin{array}{l}\text { cropping season II: } \\
\text { - paddy } \\
\text { - second crop }\end{array}$ & $\begin{array}{r}500 \\
0\end{array}$ & $\begin{array}{r}0 \\
500\end{array}$ & \\
\hline & $\begin{array}{l}\text { cropping season III: } \\
\text { - paddy } \\
\text { - second crop }\end{array}$ & $\begin{array}{r}0 \\
128\end{array}$ & $\begin{array}{l}200 \\
300\end{array}$ & \\
\hline \multirow{3}{*}{ 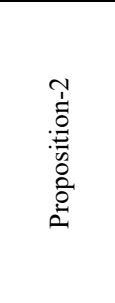 } & $\begin{array}{l}\text { cropping season I: } \\
\text { - paddy } \\
\text { - second crop }\end{array}$ & $\begin{array}{r}500 \\
0\end{array}$ & $\begin{array}{l}350 \\
150\end{array}$ & \multirow{3}{*}{$1,442,631.04$} \\
\hline & $\begin{array}{l}\text { cropping season II: } \\
\text { - paddy } \\
\text { - second crop }\end{array}$ & $\begin{array}{l}251 \\
249\end{array}$ & $\begin{array}{l}235 \\
265\end{array}$ & \\
\hline & $\begin{array}{l}\text { cropping season III: } \\
\text { - paddy } \\
\text { - second crop }\end{array}$ & $\begin{array}{r}0 \\
128\end{array}$ & $\begin{array}{r}0 \\
300\end{array}$ & \\
\hline \multirow{3}{*}{ 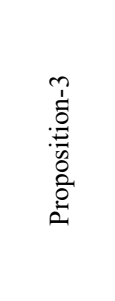 } & $\begin{array}{l}\text { cropping season I: } \\
\text { - paddy } \\
\text { - second crop }\end{array}$ & $\begin{array}{r}500 \\
0 \\
\end{array}$ & $\begin{array}{r}500 \\
0 \\
\end{array}$ & \multirow{3}{*}{$1,342,990.20$} \\
\hline & $\begin{array}{l}\text { cropping season II: } \\
\text { - paddy } \\
\text { - second crop }\end{array}$ & $\begin{array}{r}323 \\
0\end{array}$ & $\begin{array}{r}500 \\
0\end{array}$ & \\
\hline & $\begin{array}{l}\text { cropping season III: } \\
\text { - paddy } \\
\text { - second crop }\end{array}$ & $\begin{array}{r}0 \\
128\end{array}$ & $\begin{array}{l}250 \\
250\end{array}$ & \\
\hline
\end{tabular}

Source: own study.

\section{CONCLUSIONS}

1. Based on the basic year method which is analysed by using the rainfall data from 2004 until 2013, the dependable rainfall for paddy $\left(R_{80}\right)$ is happened on the 2005 with the yearly rainfall is $1,019 \mathrm{~mm}$. However, the dependable rainfall for the second crop $\left(R_{50}\right)$ is happened on the 2011 with the yearly rainfall is $1,023 \mathrm{~mm}$. Then, the analysis of effective rainfall for paddy and the second crop are based on the result as above.
2. Based on the data analysis by using the Weibull method, it is obtained the dependable discharge of $80 \%$ in the Parsanga irrigation area is in amount of $0.572 \mathrm{~m}^{3} \cdot \mathrm{s}^{-1}$. The basic year of the dependable discharge is on the 2010 .

3. The maximum benefit is obtained from the proposition-2 cropping pattern (paddy/second crop paddy/second crop - second crop) that produces the benefit in amount of USD 1,442,631.03.

\section{REFERENCES}

Abdulkader A.M.A., Amoud A.I.A., Awad F.S. 2012. Optimization of the cropping pattern in Saudi Arabia. Agricultural Economics - Czech. Vol. 58. Iss. 2 p. 5660.

Gakpo E., Tsephe J., Nwonwu F., Vilkoen M. 2006. Application of stochastic programming (SDP) for the optimal allocation of irrigation water under capacity sharing arrangements. Agrekon, Agricultural Economics Association of South Africa (AEASA). Vol. 44. No. 4 p. 436-451.

GuPTA I., ZAAG P.V.D. 2007. Inter-basin water transfers and integrated water resources management: where engineering, science and politics interlock. Journal of Physics and Chemistry of the Earth. Vol. 33 p. 28-40.

Gupta N., Pilesjo P., Maathuis D. 2010. Use of geoinformatics for Inter-Basin water transfer assessment. Journal of Water Resources: Water Resources and the Regime of Water Bodies. Vol. 37. No. 3 p. 623-637.

HAOUARI M., AZAIEZ M.N. 2001. Optimal cropping patterns under water deficits. European Journal of Operational Research. Vol. 130 p. 133-146.

Hoesein A.A., Limantara L.M. 2010. Linear Programming model for optimization water irrigation area of Jatimlerek of East Java. International Journal of Academic Research. Vol. 2. Iss. 6 p. 55-57.

INWRDAM 2001. Decision support system in the field of water resources planning and management [online]. Amman. Inter-Islamic Network on Water Resources Development and Management. [Access 12.03.2001]. Available at: http://www.nic.gov.jo/inwrdam/dss.htm1

IPCC 2007. Climate change 2007: Synthesis Report. In: Contribution of Working Groups I, II, and III to the Forth Assessment Report of the Intergovernmental Panel on Climate Change. Eds. R.K. Pachauri, A. Reisinger. Geneva, Switzerland. IPCC pp. 221.

Kaur B., Sidhu R.S., Kamal V. 2010. Optimal crop plans for sustainable water use in Punjab. Agricultural Economics Research Review. Vol. 23 p. 273-284.

LimanTARA L.M. 2007. Pengaruh perubahan cuaca terhadap optimasi irigasi dengan Program linier [The effect of climate change to optimization of irrigation by using linear programming]. Malang. CV Asrori. ISBN 979952-367-2 pp. 84.

LimANTARA L.M. 2010a. Possible climate change on water irrigation at Golek, Malang, Indonesia. International Journal of Academic Research. Ser. Economics and Engineering. Vol. 1. Iss. 3 p. 15-17.

LIMANTARA L.M. 2010b. Optimization of water needs at Kepanjen Dam and Sengguruh Dam, East Java, Indonesia. International Journal of Academic Research. Vol. 2 p. 216-218. 
LimANTARA L.M. 2010c. Hidrologi praktis [Practical hydrology]. Bandung. Lubuk Agung. ISBN 978-979-505205-2 pp. 324.

LIMANTARA L.M. 2011. Optimization of improvement and management on Sumber Brantas Watershed East Java, Indonesia. Journal of Basic and Applied Scientific Research. Vol. 1. Iss. 3 p. 231-235.

Limantara L.M., Soetopo W. 2011. Manajemen teknik sumber daya air [Water resources management]. Bandung. CV Lubuk Agung. ISBN 978-979-505-225-2 pp. 252.

MiatKOWSKi Z., SMARZYŃSKa K. 2017. Surface water resources of small agricultural watershed in the Kujawy Region, Central Poland. Journal of Water and Land Development. No. 33 p. 131-140. DOI 10.1515/jwld2017-0028.

MontaZAR A., RAHIMIKOB A. 2008. Optimal water productivity of irrigation networks in arid and semi-arid regions. Irrigation and Drainage. Vol. 57 p. 411-423.

Osama S., ElKhOlY M., KansOH R.M. 2017. Optimization of the cropping pattern in Egypt. Alexandria Engineering Journal. Vol. 56. Iss. 4 p. 557-566.

PAVONI B., VoINOV A., ZhaVORA N. 2001. Basin (watershed) approach as a methodological basis for regional decision making and management in the EX USSR [online]. [Access 12.03.2001]. Available at: http:// helios.unive.it/\%7Eintas/gaboart.htm1
PRIYANTORO D., LimANTARA L.M. 2011. Water supply system at Tibunangka irrigation area, Lombok - Indonesia. International Journal of Academic Research. Ser. Mathematical and Technology. Vol. 2. Iss. 1 p. 8-13.

SATTARI T.M., KodAl S., ÖZTÜRK F. 2006. Application of deterministic mathematical method in optimizing the small irrigation reservoir capacity. Journal of Akdeniz Universitesi Ziraat Fakoltesi Dergisi. Vol. 19. Iss. 2 p. 261-267.

Sethi L.N., Panda S.N., NAyaK M.K. 2006. Optimal crop planning and water resources allocation in a coastal groundwater basin, Orissa, India. Agricultural Water Management. No. 83 p. 209-220.

Singh D.K., Jaiswalb C.S., RedDYa K.S., Singha R.M., BHANDARKAR D.M. 2001. Optimal cropping pattern in a canal command area. Agricultural Water Management. Vol. 50. Iss. 1 p. 1-8.

Vivekanandan N., Viswanathan K., SANJeev G. 2009. Optimization of cropping pattern using goal programming approach. OPSEARCH. No. 46 p. 259-274. DOI 10.1007/s12597-009-0017-y.

Zhou H., Hui P., CHi Z. 2007. An interactive fuzzy multiobjective optimization approach for crop planning and water resources allocation. In: Bio-inspired computational intelligence and applications. Eds. K. Li, M. Fei, G.W. Irwin, S. Ma. Lecture Notes in Computer Science. No. 4688. Berlin-Heidelberg. Springer p. 335-346.

\section{Pitojo T. JUWONO, Lily Montarcih LIMANTARA, Fathor ROSIADI}

\section{Optymalizacja systemu nawadniania upraw za pomoca programowania linearnego - przykład nawadnianego obszaru Parsanga, wyspa Madura, Indonezja}

\section{STRESZCZENIE}

Nawadniany obszar Parsanga znajduje się w dystrykcie Sumenep na wyspie Madura w Indonezji. Ma powierzchnię 500 ha, a system upraw tam stosowanych to ryż-ryż-drugi plon. W warunkach takiego systemu uprawy występują deficyty wody, szczególnie w porze suchej. Z tego powodu przedstawione badania miały na celu optymalizację systemu upraw w trzech systemach, aby uzyskać maksymalne korzyści w produkcji rolniczej. Trzy systemy to: 1 - ryż/drugi plon-drugi plon-ryż/drugi plon, 2 - ryż/drugi plon-ryż/drugi plon-drugi plon i 3 - ryż-drugi plon-ryż/drugi plon. Optymalizację wykonano z zastosowaniem programowania linearnego. Sugerowane trzy systemy są w stanie nie tylko rozwiązać problem deficytu wody, ale także dają korzyści produkcyjne większe niż obecnie uzyskiwane.

Słowa kluczowe: nawadnianie, optymalizacja, Parsanga, programowanie liniowe, system upraw 